\title{
Mannose-binding lectin deficiency and acute exacerbations of chronic obstructive pulmonary disease
}

This article was published in the following Dove Press journal:

International Journal of COPD

22 November 2012

Number of times this article has been viewed

\author{
Richard K Albert' \\ John Connett ${ }^{2}$ \\ Jeffrey L Curtis ${ }^{3,4}$ \\ Fernando J Martinez ${ }^{3}$ \\ MeiLan K Han ${ }^{3}$ \\ Stephen C Lazarus ${ }^{5}$ \\ Prescott G Woodruff ${ }^{5}$ \\ 'Medicine Service, Denver Health and \\ Department of Medicine, University \\ of Colorado Denver, Denver, CO, \\ ${ }^{2}$ Division of Biostatistics, School of \\ Public Health, University of Minnesota, \\ Minneapolis, MN, ${ }^{3}$ Pulmonary and \\ Critical Care Medicine, Department \\ of Medicine, University of Michigan, \\ Ann Arbor, MI, ${ }^{4}$ Pulmonary and \\ Critical Care Medicine, VA Medical \\ Center, Ann Arbor, MI, ${ }^{5}$ Pulmonary and \\ Critical Care Medicine, Department \\ of Medicine, and Cardiovascular \\ Research Institute, University of \\ California, San Francisco, CA, USA
}

Correspondence: Richard K Albert Email ralbert@dhha.org
Background: Mannose-binding lectin is a collectin involved in host defense against infection. Whether mannose-binding lectin deficiency is associated with acute exacerbations of chronic obstructive pulmonary disease is debated.

Methods: Participants in a study designed to determine if azithromycin taken daily for one year decreased acute exacerbations had serum mannose-binding lectin concentrations measured at the time of enrollment.

Results: Samples were obtained from 1037 subjects (91\%) in the trial. The prevalence of mannose-binding lectin deficiency ranged from $0.5 \%$ to $52.2 \%$, depending on how deficiency was defined. No differences in the prevalence of deficiency were observed with respect to any demographic variable assessed, and no differences were observed in time to first exacerbation, rate of exacerbations, or percentage of subjects requiring hospitalization for exacerbations in those with deficiency versus those without, regardless of how deficiency was defined.

Conclusion: In a large sample of subjects with chronic obstructive pulmonary disease selected for having an increased risk of experiencing an acute exacerbation of chronic obstructive pulmonary disease, only $1.9 \%$ had mannose-binding lectin concentrations below the normal range and we found no association between mannose-binding lectin concentrations and time to first acute exacerbation or frequency of acute exacerbations during one year of prospective follow-up.

Keywords: COPD, acute exacerbations, mannose-binding lectin

\section{Introduction}

Mannose-binding lectin (MBL) is a pattern-recognition collectin that is related to surfactant proteins $\mathrm{A}$ and $\mathrm{D}$ and has two roles in host defense. MBL activates complement via serine proteases, particularly MBL-associated serine protease-2, with which it circulates. ${ }^{1,2} \mathrm{MBL}$ is also involved in opsonophagocytosis, binding several types of pathogens to phagocytes via its carbohydrate recognition domain, triggering release of a number of proinflammatory cytokines ${ }^{3-5}$ and facilitating clearance of apoptotic cells. ${ }^{6}$

MBL is secreted primarily by the liver and circulates in the serum. Low MBL concentrations occur as a result of one of three single nucleotide polymorphisms on exon 1, but the most common cause of deficiency in Caucasians is the LXP haplotype resulting from polymorphisms of the promoter region of the gene, presenting either as a homozygous mutation or in combination with other haplotypes. ${ }^{7-9}$

Several observations suggest that MBL deficiency may compromise host defense in the lungs. MBL binds to carbohydrates on the surface of a number of respiratory pathogens that are associated with acute exacerbations of chronic obstructive pulmonary disease 
(COPD), including Haemophilus influenzae, ${ }^{10,11}$ Mycoplasma pneumoniae, ${ }^{12}$ and influenza. ${ }^{13}$ Patients with cystic fibrosis and low MBL concentrations have decreased lung function, an increased prevalence of Burkholderia cepacia infection, and reduced survival relative to patients with cystic fibrosis and normal MBL concentrations. The difference in survival is particularly notable in those with chronic Pseudomonas aeruginosa infection and those with homozygous mutations in the MBL-2 gene. ${ }^{14-17}$ Low MBL concentrations have been associated with an increased risk of respiratory infections in immunocompetent subjects, ${ }^{18-21}$ with an increased frequency of respiratory syncytial virus infections, ${ }^{22}$ and with worse outcomes in patients with community-acquired pneumonia and Streptococcus pneumoniae infections. ${ }^{23-26} \mathrm{MBL}$ concentrations in bronchoalveolar lavage fluid obtained from a small number of current and former smokers with COPD are lower than those in fluid from healthy controls and tend to be higher in former smokers than in current smokers, ${ }^{27,28}$ but no association has been found between genotypes producing low MBL concentrations and the prevalence of COPD. ${ }^{29}$ However, studies assessing the association of low MBL concentrations with acute exacerbations of COPD (AECOPDs) report conflicting results. ${ }^{30-32}$ Accordingly, we prospectively measured MBL concentrations in a large cohort of subjects with COPD who were at increased risk of experiencing acute exacerbations and followed them for one year while tracking the number of acute exacerbations that occurred. Our hypothesis was that subjects with COPD who had an increased risk of experiencing an AECOPD would have more frequent acute exacerbations during one year of follow-up if they were deficient in MBL than if they were not.

\section{Materials and methods}

\section{Patient population}

Subjects were men and women enrolled in a multicenter randomized trial designed to determine if azithromycin, taken daily for one year, decreased the frequency of AECOPDs. ${ }^{33}$ Eligibility criteria included age $\geq 40$ years, a clinical diagnosis of COPD, and an increased risk of experiencing an AECOPD based on criteria defined by Niewoehner et al. ${ }^{34}$ Patients had to be free of AECOPDs for a minimum of 4 weeks prior to enrollment. Exclusion criteria included a diagnosis of asthma or bronchiectasis, among others. ${ }^{33}$

Acute exacerbations were defined as "a complex of respiratory symptoms (increased or new onset) of more than one of the following: cough, sputum, wheezing, dyspnea, or chest tightness with a duration of at least three days requiring treatment with antibiotics or systemic steroids". ${ }^{34}$

\section{MBL assays}

Serum was collected at the time subjects were enrolled in the study when they had not experienced an AECOPD for a minimum of 4 weeks and was stored at $-80^{\circ} \mathrm{C}$ until MBL concentrations were assayed by enzyme-linked immunosorbent assay (R \& D Systems, Minneapolis, MN). Samples were diluted 1/500 for this assay and assayed in duplicate wells. At this dilution, the range of the standard curve corresponds to concentrations ranging from $78 \mathrm{ng} / \mathrm{mL}$ to $5000 \mathrm{ng} / \mathrm{mL}$. When concentrations were extrapolated above $5450(n=7)$ or below $60(n=6)$, the samples were reassayed at either a $1 / 2500$ or a $1 / 20$ dilution and these new values used as MBL serum concentrations. In one case, a sample was still less than the detection limit at $1 / 20$ dilution and this sample was assigned the concentration of less than $3 \mathrm{pg} / \mathrm{mL}$.

The MBL concentration that defines MBL deficiency is debated. Some define deficiency as a serum concentration $<500 \mathrm{ng} / \mathrm{mL} .^{24,31,35,36}$ Others define it as $\leq 100 \mathrm{ng} / \mathrm{mL}$, and still others define severe deficiency as $\leq 50 \mathrm{ng} / \mathrm{mL}$ and partial deficiency as $>50 \mathrm{ng} / \mathrm{mL}$ but $<1000 \mathrm{ng} / \mathrm{mL}$. ${ }^{9,10,21,25,31,37-40}$ The normal value reported by the manufacturer of the assay is $1135 \mathrm{ng} / \mathrm{mL}$ with a range of 103-3308 ng/mL (R\&D Systems). Because of these uncertainties, we defined MBL deficiency in four ways, ie, $\leq 50 \mathrm{ng} / \mathrm{mL}, \leq 100 \mathrm{ng} / \mathrm{mL}, \leq 500 \mathrm{ng} / \mathrm{mL}$, and $>50$ but $\leq 1000 \mathrm{ng} / \mathrm{mL}$.

Azithromycin increases expression of the mannose receptor, and uptake of apoptotic cells by human alveolar macrophages, and decreases recovery of apoptotic bronchial epithelial cells. ${ }^{27}$ Accordingly, MBL concentrations from patients randomized to receive azithromycin or placebo were analyzed both separately and together.

\section{Statistical analysis}

A Cox proportional-hazards model analysis was used with time-to-first-exacerbation as the outcome variable and MBL group (ie, below versus above specified limits) as the primary variable of interest. Bootstrap methods were used to compute confidence intervals for median survival times. Rates of AECOPDs were determined by dividing the number of AECOPDs by person-years of follow-up and were analyzed as a function of MBL concentration using a negative binomial model.

MBL concentrations are presented as medians and interquartile ranges. $P<0.05$ was considered to be statistically significant. The study (ClinicalTrials.gov number NCT00325897) was approved by the institutional review boards at all participating centers. 


\section{Results}

MBL assays were performed at baseline in 1037 (91\%) of the 1142 subjects enrolled in the azithromycin trial. Of these, 909 had experienced one or more AECOPDs in the year prior to enrollment. Duplicate measurements of MBL had coefficients of variations $<15 \%$ in all cases and $<5 \%$ in most.

The median MBL concentration for all patients was $918 \mathrm{ng} / \mathrm{mL}$ (interquartile range $508-1683 \mathrm{ng} / \mathrm{mL}$, inclusive range $0-8194 \mathrm{ng} / \mathrm{mL}$ ). The median MBL concentration in subjects randomized to receive azithromycin or placebo was $1008 \mathrm{ng} / \mathrm{mL}$ (95\% confidence interval [CI] 909-1082) and $850 \mathrm{ng} / \mathrm{mL}$ (95\% CI 776-929), respectively ( $P=0.017)$.

Patient demographics and clinical characteristics, stratified by MBL concentration, are summarized in Table 1. The prevalence of MBL deficiency was $0.5 \%, 1.9 \%, 24.2 \%$, or $52.3 \%$, when deficiency was defined as $\leq 50, \leq 100, \leq 500$, or $>50$ and $\leq 1000 \mathrm{ng} / \mathrm{mL}$, respectively (Table 1 ). Regardless of the concentration of MBL used to define MBL deficiency, no difference was observed with respect to the prevalence of MBL deficiency by gender, race, or age (with the exception that a greater fraction of women had MBL deficiency defined as $>50 \mathrm{ng} / \mathrm{mL}$ and $\leq 1000 \mathrm{ng} / \mathrm{mL}$ than was seen with the other definitions), smoking status, chronic bronchitis, or steroid use, and there was no suggestion that airflow limitation was worse or that GOLD (Global Initiative for Chronic Obstructive Lung Disease) stage was higher in subjects with MBL deficiency (Table 1). The same findings were also observed for the subgroups of subjects receiving azithromycin or placebo (data not shown).

When analyzing time-to-first AECOPD using a model that included treatment group (ie, azithromycin versus placebo) and log-transformed MBL concentration stratified by clinic, treatment group was significant $(P<0.0001)$ and log-transformed MBL concentration was not $(P=0.629)$. The hazard ratio for a one-unit increase in log-transformed MBL concentration was 1.02 (95\% CI 0.94-1.12). For the rate per person-year of AECOPDs, a negative-binomial analysis of a model that included treatment group and log-transformed MBL concentration found that treatment group was significant $(P=0.010)$ but log-transformed MBL concentration was not $(P=0.470)$. The coefficient for log-transformed MBL concentration in this model was $0.031(95 \% \mathrm{CI},-0.053$ to +0.115$)$.

The median time to first AECOPD and the rate of AECOPD per patient-year are shown in Figures 1-3 and in Table 2 relative to the various definitions of MBL deficiency (only five patients had MBL concentrations $\leq 50 \mathrm{ng} / \mathrm{mL}$, precluding life table analyses for patients in this subgroup). Regardless of the MBL concentration used to define deficiency, no association between the time to first AECOPD, or the rate of AECOPDs and MBL concentration was observed in the population as a whole, or in either treatment subgroup. Nonsignificant trends favoring a longer time to first AECOPD were seen in the subgroup of subjects with MBL concentrations $<100 \mathrm{ng} /$ $\mathrm{mL}$ compared with those with concentrations $\geq 100 \mathrm{ng} / \mathrm{mL}$ (Figure 1A and C). No difference was observed in MBL concentrations in subjects experiencing no, one, two, or at least three AECOPDs during the course of the study in the population as a whole, or in either treatment group (Table 3).

Of the 1037 subjects in the study, 220 (21\%) required hospitalization for AECOPDs. The median MBL concentration in these 220 subjects was 1055 (95\% CI 861-1213) ng/mL [1091 (958-1450) for those on azithromycin and 891 (816-1276) for those on placebo]. The median MBL concentration in the 817 subjects who were not hospitalized was 904 (833-980, $P=0.17$, Table 4).

\section{Discussion}

The important findings of this study are that, in this large sample of subjects with COPD selected for having an increased risk of experiencing an AECOPD within one year, only $1.9 \%$ had MBL concentrations below the normal range reported by the manufacturer of the assay, and regardless of the MBL concentration used to define MBL deficiency, we found no association between deficiency and time to first AECOPD, rate of AECOPDs, or need for subjects to be hospitalized for AECOPDs.

Two studies concluded that MBL deficiency was associated with an increased incidence of AECOPDs and one concluded that it was not. The age, spirometry, and smoking histories of the subjects in these three studies were similar to those we evaluated, with the exception that none of the three studies selected patients who were at increased risk of experiencing acute exacerbations as we did. Yang et $\mathrm{al}^{30}$ found that 24 of $82(29 \%)$ subjects with COPD had MBL-deficient genotypes. These subjects had lower MBL concentrations than those with the wild-type genotype (107 ng/mL, IQR 30-246, range 21-7675 versus $920 \mathrm{ng} / \mathrm{mL}$, IQR 398-1355, range 21-2256, $P<0.001)$. MBL concentrations were not presented in a fashion that allowed determination of the prevalence of MBL deficiency based on the definitions used in the literature. Forty of the 82 patients $(49 \%)$ had one or more admissions for AECOPDs during a two-year follow-up period and 18 of these (45\%) had MBL-deficient genotypes. Forty-two patients had no AECOPDs and only six (14\%) of these had MBL-deficient genotypes (odds ratio 4.9 95\% CI 1.7-14.4, $P=0.0037$ ). We did not determine MBL genotypes but genotypes do not 


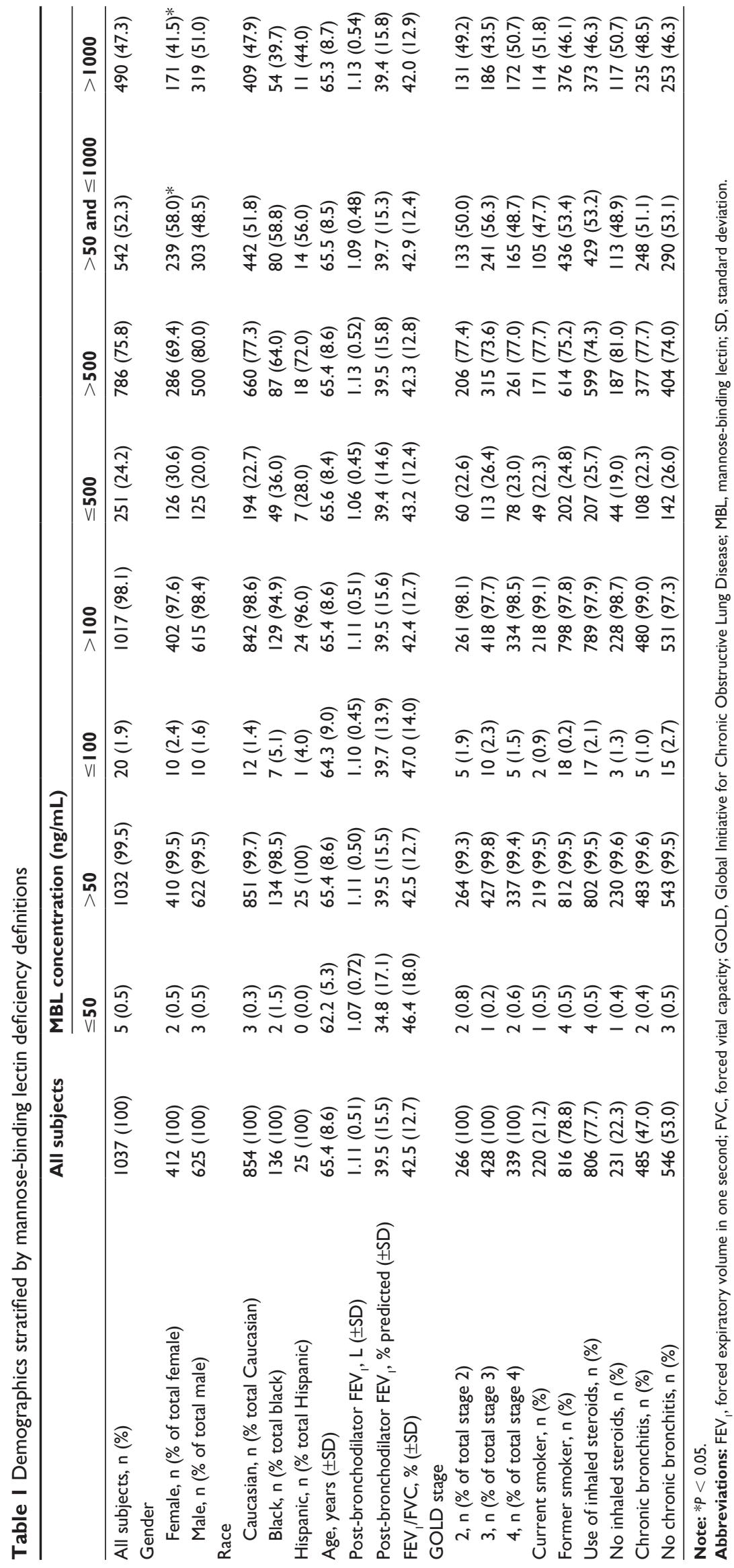



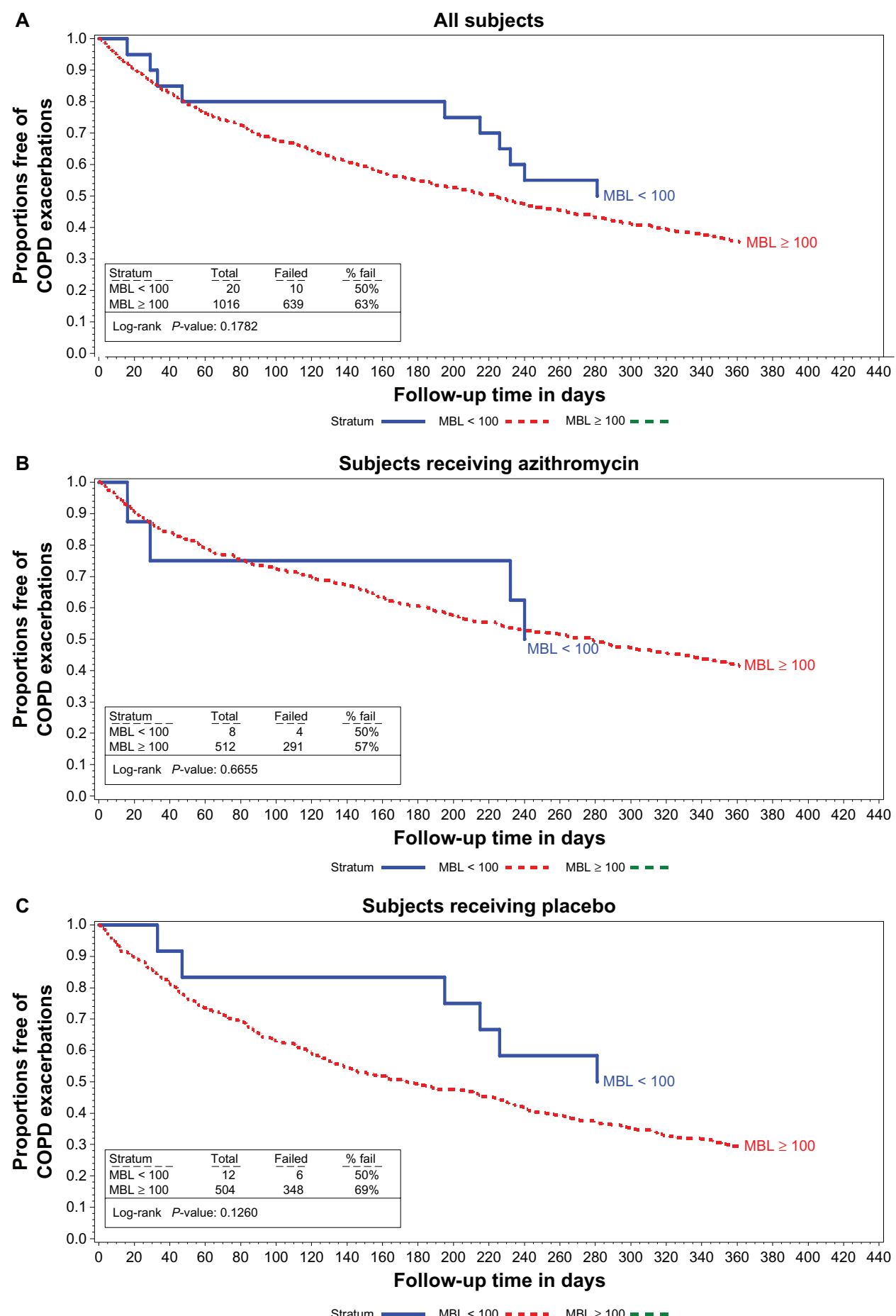

Figure I Proportions free of exacerbations MBL concentrations $<100$ vs 100 or larger in all subjects $(\mathbf{A})$ subjects receiving azithromycin (B) and in subjects receiving the placebo (C).

Abbreviations: COPD, chronic obstructive pulmonary disease; MBL, mannose binding lectin.

accurately predict MBL concentrations (see below, and note that at least one of the subjects with an MBL-deficient genotype included in the study by Yang et al had an MBL concentration of $7675 \mathrm{ng} / \mathrm{mL}$ and one with the wild-type genotype had an MBL concentration of $21 \mathrm{ng} / \mathrm{mL}$ ).
Lin et a ${ }^{32}$ studied 215 Chinese subjects with COPD. MBL concentrations were again not presented in a fashion that allowed determination of the prevalence of MBL deficiency by literature-based definitions, but the median MBL concentration they reported of $777 \mathrm{ng} / \mathrm{mL}$ was comparable with the 

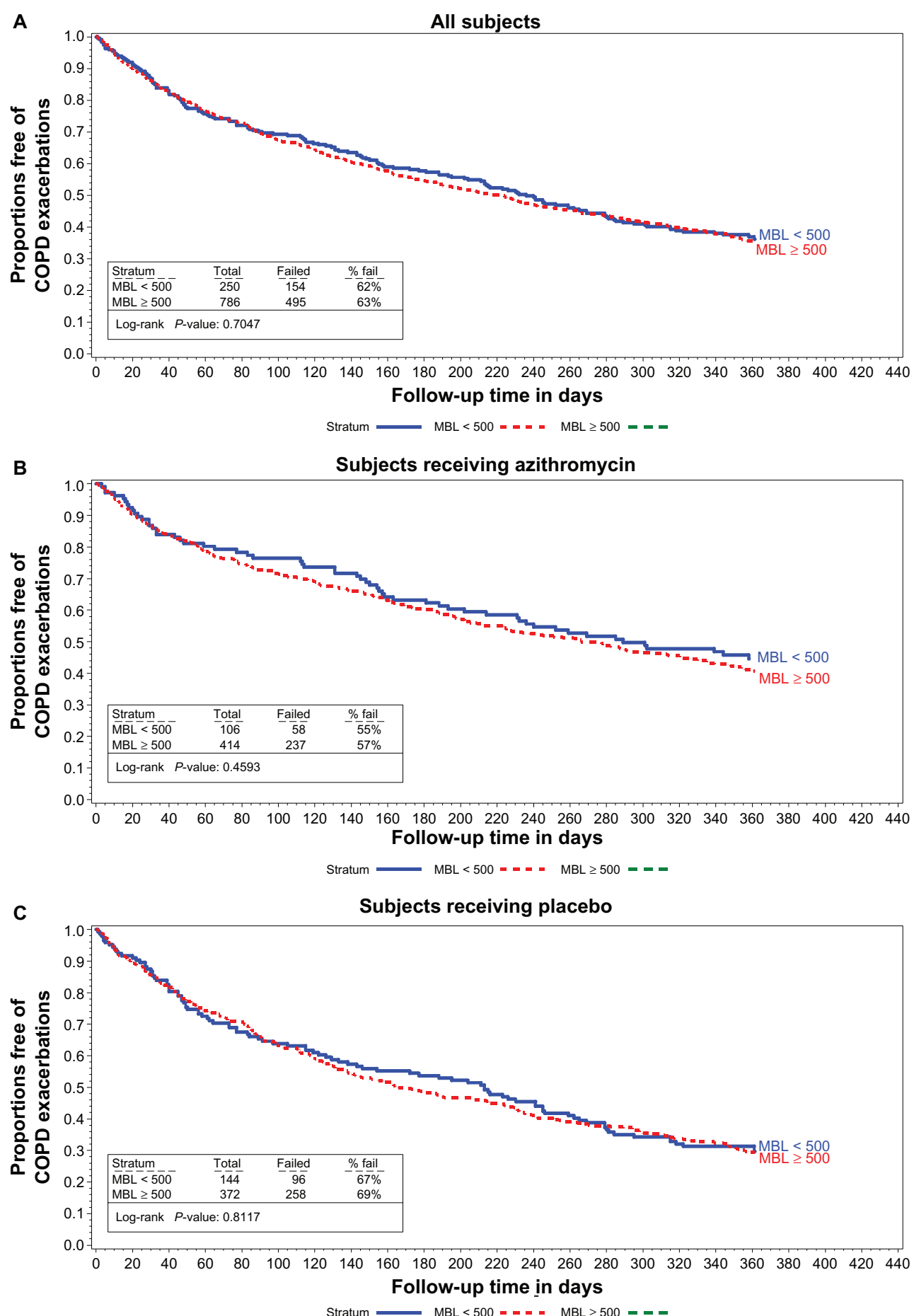

Figure 2 Proportions free of exacerbations MBL concentrations $<500$ vs 500 or larger in all subjects (A) subjects receiving azithromycin (B) and in subjects receiving the placebo (C).

Abbreviations: COPD, chronic obstructive pulmonary disease; MBL, mannose binding lectin.

median of $918 \mathrm{ng} / \mathrm{mL}$ that we observed. In 96 of their subjects who had three or more AECOPDs per year over a 3-year period, the mean MBL concentration was $534 \pm 932 \mathrm{ng} / \mathrm{mL}$ compared with $1127 \pm 1469 \mathrm{ng} / \mathrm{mL}$ in subjects with two or fewer exacerbations $(P=0.027)$. Twelve of the 96 more frequent exacerbators $(12.5 \%)$ had MBL genotypes associated with MBL deficiencies compared with only 5/119
(4.2\%) of the less frequent exacerbators $(P=0.025)$. Patients with MBL-deficient genotypes also had a higher mortality (66.7\% versus $31.0 \%$, respectively, $P=0.015$ ).

However, in a cross-sectional study, Eagan et $\mathrm{al}^{31}$ found that $18.2 \%$ and $42.9 \%$ of healthy Norwegian subjects had MBL concentrations $\leq 100 \mathrm{ng} / \mathrm{mL}$ and $\leq 500 \mathrm{ng} / \mathrm{mL}$, respectively, compared with $22.2 \%$ and $49.6 \%$ of subjects with 




A

All subjects

B

Subjects receiving azithromycin

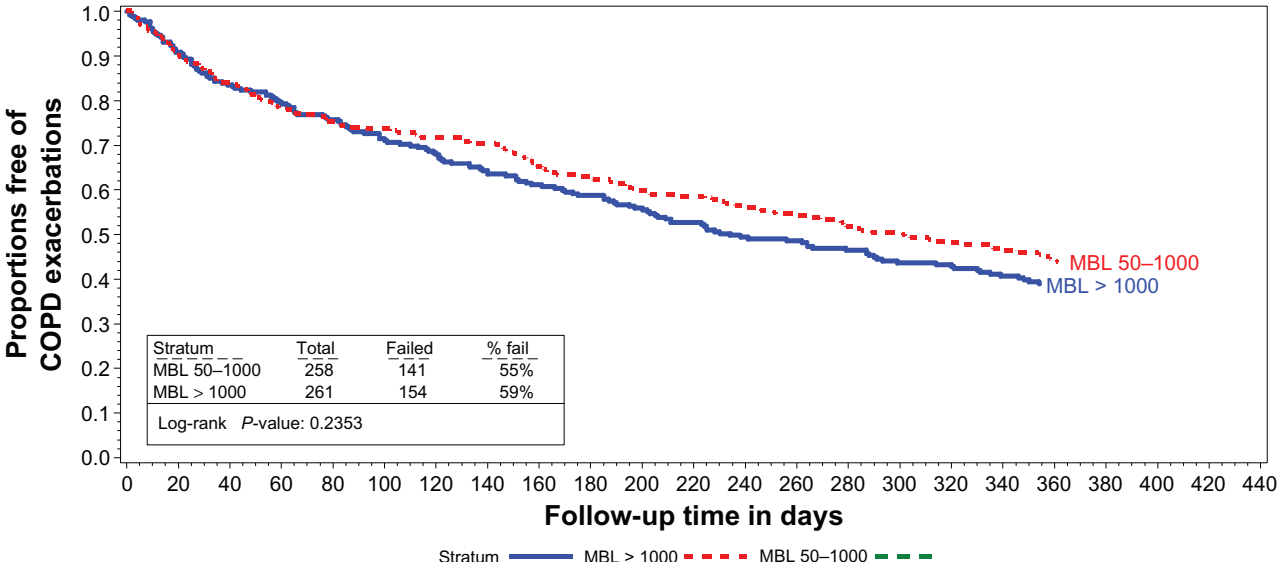

C

Subjects receiving placebo



Figure 3 Proportions free of exacerbations MBL concentrations between 50 and 1000 vs 1000 or larger in all subjects (A) subjects receiving azithromycin (B) and in subjects receiving the placebo $(\mathbf{C})$.

Abbreviations: COPD, chronic obstructive pulmonary disease; MBL, mannose binding lectin.

COPD ( $P=0.23$ and $P=0.10$, respectively). No association between MBL concentration and a history of AECOPDs was observed, but no information was provided with respect to how AECOPDs were defined. Eagan et $\mathrm{al}^{31}$ also noted that subjects with GOLD stage 3 disease had a higher prevalence of MBL deficiency (defined as $\leq 100 \mathrm{ng} / \mathrm{mL}$ ). We found no demographic or COPD severity indicators that were more or less common in subjects with MBL deficiency, regardless of how deficiency was defined (Table 1).

The strengths of our study include the large sample size, the multicenter design, and the prospective ascertainment of AECOPDs using an event-based (ie, health care utilization) definition. Our study population was enriched by enrolling subjects whom we anticipated would be at increased 
Table 2 Association of mannose-binding lectin concentration with acute COPD exacerbations

\begin{tabular}{|c|c|c|c|c|c|c|}
\hline \multirow[t]{2}{*}{ Variable } & \multicolumn{6}{|c|}{ MBL concentration (ng/mL) } \\
\hline & $\leq 100$ & $>100$ & $\leq \mathbf{5 0 0}$ & $>500$ & $>50$ and $\leq 1000 * *$ & $>1000$ \\
\hline \multicolumn{7}{|c|}{ Days to first AECOPD, median $(95 \% \mathrm{Cl})$} \\
\hline All patients & $326(215-370)$ & $223(193-242)$ & $236(193-279)$ & $223(188-242)$ & $231(194-266)$ & $211(175-242)$ \\
\hline Azithromycin & NA* & $277(227-320)$ & $289(214, \geq 375)$ & $266(223-320)$ & $302(245-376)$ & 234 (197-299) \\
\hline Placebo & $326(215-370)$ & $173(139-215)$ & $213(133-246)$ & $166(136-216)$ & $178(|3|-224)$ & $17 \mid(136-232)$ \\
\hline \multicolumn{7}{|c|}{ Rate of AECOPD per patient-year $(95 \% \mathrm{Cl})$} \\
\hline All patients & $1.03(0.47-1.59)$ & $1.65(1.50-1.80)$ & $1.70(1.29-2.11)$ & $1.62(1.48-1.76)$ & $1.67(1.44-1.90)$ & $1.6 \mathrm{I}(1.44-1.79)$ \\
\hline Azithromycin & $1.04(0.00-2.25)$ & I.46 (I.29-I.63) & $1.29(0.96-1.62)$ & $1.50(1.30-1.70)$ & $1.43(1.18-1.68)$ & $1.49(1.25-1.72)$ \\
\hline Placebo & I.03 (0.34-I.7I) & $\mathrm{I} .84(\mathrm{I} .6 \mathrm{I}-2.08)$ & $2.01(1.34-2.67)$ & $1.75(1.56-1.95)$ & $1.89(1.52-2.26)$ & $1.76(1.5 \mathrm{I}-2.02)$ \\
\hline
\end{tabular}

Notes: *Too few patients for life table analysis; **number of subjects in this column is one greater than the number indicated on Figure 3 because the life table analyses were truncated at 365 days eliminating one patient.

Abbreviations: AECOPD, acute exacerbations of chronic obstructive pulmonary disease; $\mathrm{Cl}$, confidence interval; $\mathrm{MBL}$, mannose-binding lectin.

risk of experiencing an AECOPD within the one-year follow-up period, based on previous predictors identified by Niewoehner et al. ${ }^{34}$ This should have increased the likelihood of finding a higher prevalence of MBL deficiency, regardless of how deficiency was defined, compared with the prevalence in healthy controls.

Our study has a number of limitations. First, we only measured MBL concentrations on one occasion. Several groups have demonstrated that MBL is an acute phase reactant. ${ }^{41-43}$ However, in clinically stable patients, MBL concentrations are constant over time, ${ }^{42,44}$ and our patients had to be free of AECOPDs for at least 4 weeks before meeting inclusion criteria. In addition, even during acute phase responses, MBL concentrations in patients with low concentrations only increase by 1.5-4.3-fold and do not reach normal values. ${ }^{45,46}$

Accordingly, we suggest that there is a low likelihood of our data being confounded by spuriously elevated concentrations of MBL resulting in an underestimate of the prevalence of MBL deficiency.

We did not confirm by genotyping that low MBL concentrations were the result of variant alleles. Approximately $30 \%$ and $4 \%-8 \%$ of the normal population have heterozygous or homozygous genetic mutations, respectively, associated with low MBL concentrations. ${ }^{35}$ Although MBL concentrations are well correlated with genotypes, (eg, MBL concentrations $<50 \mathrm{ng} / \mathrm{mL}$ are $100 \%$ sensitive and $83 \%$ specific for variant exon-1 polymorphisms ${ }^{43}$ ) subjects with wild-type MBL genes may still have low concentrations of MBL, ${ }^{35}$ and $\mathrm{MBL}$ concentrations may vary as much as 10-fold in patients with identical genotypes for all of the MBL variants described to date. ${ }^{38}$ Accordingly, assessing relationships between MBL concentrations and AECOPDs is likely to be a more sensitive approach than genotyping. ${ }^{21,25}$

Table 3 Association of mannose-binding lectin concentration with number of COPD exacerbations

\begin{tabular}{|c|c|c|c|c|c|c|}
\hline \multirow[t]{2}{*}{ Variable } & \multicolumn{6}{|c|}{ MBL concentration $(\mathrm{ng} / \mathrm{mL})$} \\
\hline & $\leq 100$ & $>100$ & $\leq \mathbf{5 0 0}$ & $>\mathbf{5 0 0}$ & $>50$ and $\leq 1000$ & $>1000$ \\
\hline Total subjects, $\mathrm{n}$ & 20 & 1017 & 251 & 786 & 542 & 490 \\
\hline \multicolumn{7}{|c|}{ Frequency of AECOPDs (all subjects), n (\%) } \\
\hline 0 & $9(45 \%)$ & $372(37 \%)$ & $95(38 \%)$ & $286(36 \%)$ & $202(37 \%)$ & $176(36 \%)$ \\
\hline $1-2$ & $9(45 \%)$ & $425(42 \%)$ & 105 (42\%) & $329(42 \%)$ & $223(41 \%)$ & $209(43 \%)$ \\
\hline$\geq 3$ & $2(10 \%)$ & $220(22 \%)$ & $51(20 \%)$ & I7I (22\%) & $117(22 \%)$ & $105(21 \%)$ \\
\hline Frequency of AECOPDs & 8 & 512 & 106 & $4 \mid 4$ & 258 & 261 \\
\hline \multicolumn{7}{|c|}{ (subjects receiving azithromycin), n (\%) } \\
\hline 0 & $4(50 \%)$ & $220(43 \%)$ & $48(45 \%)$ & 176 (43\%) & II 6 (45\%) & $107(4 \mid \%)$ \\
\hline $\mathrm{I}-2$ & $3(38 \%)$ & 193 (38\%) & 40 (38\%) & 156 (38\%) & $92(36 \%)$ & $104(40 \%)$ \\
\hline$\geq 3$ & $\mathrm{I}(13 \%)$ & 99 (19\%) & $18(17 \%)$ & $82(20 \%)$ & $50(19 \%)$ & $50(19 \%)$ \\
\hline Frequency of AECOPDs & 12 & 505 & 145 & 372 & 284 & 229 \\
\hline \multicolumn{7}{|c|}{ (subjects receiving placebo), n (\%) } \\
\hline 0 & $5(42 \%)$ & $152(30 \%)$ & 47 (32\%) & $110(30 \%)$ & $86(30 \%)$ & $69(30 \%)$ \\
\hline $\mathrm{I}-2$ & $6(50 \%)$ & $232(46 \%)$ & $65(45 \%)$ & $173(47 \%)$ & $131(46 \%)$ & 105 (46\%) \\
\hline$\geq 3$ & $\mathrm{I}(8 \%)$ & I2I (24\%) & $33(23 \%)$ & $89(24 \%)$ & $67(24 \%)$ & 55 (24\%) \\
\hline
\end{tabular}

Abbreviations: AECOPD, acute exacerbations of chronic obstructive pulmonary disease; MBL, mannose-binding lectin. 
Table 4 Relationship between mannose-binding lectin concentrations and hospitalization for acute exacerbations of chronic obstructive pulmonary disease

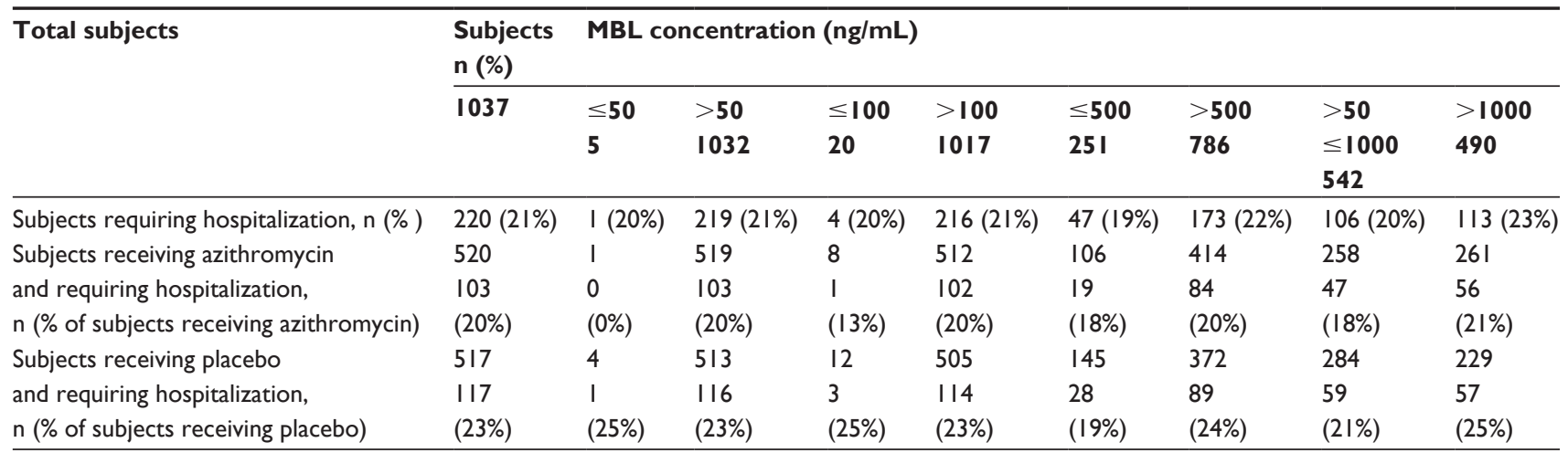

Abbreviation: MBL, mannose-binding lectin.

Similarly, we did not assess MBL function using a complement deposition assay. Bouwman et $\mathrm{al}^{47}$ and Eisen ${ }^{48}$ suggested that while MBL function was a better way of defining MBL deficiency than determining MBL concentrations, assessing MBL concentrations was "most appropriate" for defining MBL deficiency in studies seeking associations with infections. Differences between MBL binding and complement activation may vary depending on the method of assessment, ${ }^{49}$ and MBL concentrations from $500 \mathrm{ng} / \mathrm{mL}$ to $1000 \mathrm{ng} / \mathrm{mL}$ are associated with decreases in function by up to $90 \%{ }^{9}$

While we saw no association between MBL deficiency and AECOPDs, MBL deficiency could still be associated with AECOPDs that result from infection with one or more specific pathogens if the frequency with which these specific pathogens affected our subjects was too low to discern the association. However, we think this possibility is unlikely, because the two studies documenting the association between MBL deficiency and AECOPDs found an association with AECOPDs that were not otherwise defined by cause or potential infecting organism. ${ }^{30,32}$ In addition, Lin et al ${ }^{32}$ found no difference in the distribution of pathogens in those subjects with AECOPD and without MBL-deficient genotypes.

Because we only found 20 subjects (1.9\%) with MBL concentrations below the lower range of normal reported by the manufacturer of the assay, we cannot exclude the possibility that very low concentrations of MBL have an association with AECOPDs. However, the infrequency of this finding implies that even if this association were found, it would pertain only to a small minority of patients suffering AECOPDs.

In conclusion, we found a very low prevalence of MBL deficiency in subjects who were at increased risk for experiencing AECOPDs and no association between MBL deficiency and time to first acute exacerbation, frequency of acute exacerbations, or percent of subjects requiring hospitalization for acute exacerbations in subjects with MBL deficiency regardless of how deficiency was defined. Accordingly, our data do not support the idea that MBL might be a therapeutic target to reduce the incidence of AECOPDs. Rather, they imply that, while COPD is an inflammatory disorder with systemic manifestations, the fundamental pathophysiology of COPD differs from conditions in which MBL deficiency seems to be a clear risk factor (ie, childhood pneumonia, rheumatoid arthritis, systemic lupus).

\section{Acknowledgments}

The hypothesis tested in this study was suggested by William Van Divier. Wilford Wong and Professor Yu-Lung Lau kindly provided additional information pertaining to MBL concentrations from subjects they had previously reported. ${ }^{24}$ This paper is published on behalf of the COPD Clinical Research Network, and is supported by National Institutes of Health-National Heart, Lung, and Blood Institute grants U10 HL074407, U10 HL074408, U10 HL074409, U10 HL074416, U10 HL074418, U10 HL074422, U10 HL074424, U10 HL074428, U10 HL074431, U10 HL074439, and U10 HL074441.

\section{Disclosure}

FJM has served on advisory boards relating to COPD or IPF-related topics for Actelion, Almirall, Bayer, Boehringer Ingelheim, BoomComm, Elan, Forest Laboratories, GlaxoSmithKline, HCRC, Ikaria, IntraMed, Jannssens, JK Associates, MedImmune/AstraZeneca, Merck/Schering-Plough, Nycomed/Takeda, Pearl Therapeutics, Novartis, Pfizer, Sudler \& Hennessey, United BioSource Corporation and 
Vertex. He has served on speaker's or CME bureaus for American Lung Association, AstraZeneca, Bayer, Boehringer Ingelheim, Center for HealthCare Education, CME Incite, ePocrates, Forest, France Foundation, GlaxoSmithKline, Lovelace Clinic, National Association for Continuing Education, Med-Ed, MedScape, Nycomed/Takeda, Potomac Center for Medical Education, Prescott, Sanofi, St Luke's Hospital, UpToDate, University of Virginia, William Beaumont Hospital. His institution has received funds from Boehringer Ingelheim for a clinical trial; has served on steering committees for clinical trials supported by Actelion, Forest Laboratories, Gilead, GlaxoSmithKline, Mpex, Nycomed/Takeda. $\mathrm{MKH}$ has participated in advisory boards for Boehringer Ingelheim GmbH, Pfizer, GlaxoSmithKline, Genentech, Novartis, Ikaria and Medimmune. She has participated on speaker's bureaus for Boehringer Ingelheim GmbH, Pfizer, GlaxoSmithKline, Grifols Therapeutics, Forest Pharmaceuticals, the National Association for Continuing Education, and WebMD. She has consulted for Novartis and Nycomed, and has received royalties from UpToDate and ePocrates, Inc. All other authors report no conflicts of interest in this work.

\section{References}

1. Ikeda K, Sannoh T, Kawasaki N, Kawasaki T, Yamashina I. Serum lectin with known structure activates complement through the classical pathway. J Biol Chem. 1987;262:7451-7454.

2. Thiel S, Vorup-Jensen T, Stover CM, et al. A second serine protease associated with manna-binding lectin that activates complement. Nature. 1997;386:506-510.

3. Soell M, Lett E, Holveck F, Scholler M, Wachsmann D, Klein JP. Activation of human monocytes by streptococcal rhamnose glues polymers is mediated by CD14 antigen and mannan binding protein inhibits TNF-alpha release. J Immunol. 1995;154:851-860.

4. Chaka W, Verheul AF, Vaishnav VV, et al. Induction of TNF-alpha in human peripheral blood mononuclear cells by the mannoprotein of Cryptococcus neoformans involves human mannose binding protein. J Immunol. 1997;159:2979-2985.

5. Jack DL, Read RC, Tenner AJ, Frosch M, Turner MW, Klein NH. Mannose-binding lectin regulates the inflammatory response of human professional phagocytes to Neisseria meningitides serogroup B. J Infect Dis. 2001;184:1152-1162.

6. Stuart LM, Takahashi K, Shi L, Savill J, Ezekowitz RAB. Mannosebinding lectin-deficient mice display defective apoptotic cell clearance but no autoimmune phenotype. J Immunol. 2005;174:3220-3226.

7. Masden HO, Satz ML, Hogh B, Svejgaard A, Garred P. Different molecular events result in low protein concentrations of mannanbinding lectin in populations from southeast Africa and South America. J Immunol. 1998;161:3169-3175.

8. Thiel S, Frederiksen PD, Hensenius JC. Clinical manifestations of mannan-binding lectin deficiency. Mol Immunol. 2006;43:86-96.

9. Bronkhorst MW, Bouwman LH. Mannose-binding lectin deficiency.

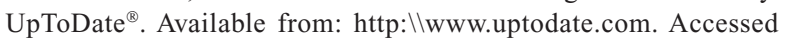
September 3, 2010.

10. Neth O, Jack DL, Dodds AW, Holzel HJ, Klein MH, Turner MW. Mannose-binding lectin binds to a range of clinically relevant microorganisms and promotes complement deposition. Infect Immun. 2000;68:688-693.
11. van Emmerick LC, Kuijper EJ, Fifjen CA, Dankert J, Thiel S. Binding of mannan-binding protein to various bacterial pathogens of meningitis. Clin Exp Immunol. 1994;97:411-416.

12. Hamvas RM, Johnson M, Vlieger AM, et al. Role for mannose binding lectin in the prevention of Mycoplasma infection. Infect Immun. 2005;73:5238-5240.

13. Anders EM, Hartley CA, Reading PC, Ezekowitz RA. Complementdependent neutralization of influenza virus by a serum mannose-binding lectin. J Gen Virol. 1994;75:615-622.

14. Garred P, Pressler T, Madsen HO, et al. Association of mannose-blinding lectin gene heterogeneity with severity of lung disease and survival in cystic fibrosis. J Clin Invest. 1999;104:431-437.

15. Gabolde M, Guilloud-Bataille M, Feingold J, Besmond C. Association of variant alleles of mannose binding lectin with severity of pulmonary disease in cystic fibrosis: cohort study. BMJ. 1999;319:1166-1167.

16. Yarden J, Radojkovic D, De Boeck K, et al. Polymorphisms in the mannose binding lectin gene affect the cystic fibrosis pulmonary phenotype. J Med Genet. 2004;41:629-633.

17. Davies JC, Turner MW, Klein N; London MBL CF Study Group. Impaired pulmonary status in cystic fibrosis adults with two mutated MBL-2 alleles. Eur Respir J. 2004;24:798-804.

18. Koch A, Melbye M, Sorensen $\mathrm{P}$, et al. Acute respiratory tract infections and mannose-binding lectin insufficiency during early childhood. JAMA. 2004;285:1316-1321.

19. Gomi K, Tokue Y, Kobayashi T, et al. Mannose-binding lectin gene polymorphism is a modulating factor in repeated respiratory infections. Chest. 2004;126:95-99.

20. Rantala A, Lajunen T, Juvonen R, et al. Mannose-binding lectin concentrations, MBL2 polymorphisms and susceptibility to respiratory tract infections in young men. J Infect Dis. 2008;198:1247-1253.

21. Hoeflich C, Unterwalder N, Schuett S, et al. Clinical manifestations of MBL deficiency in adults independent of concomitant immunodeficiency. Hum Immunol. 2009;70:809-812.

22. Ribeiro LZG, Tripp RA, Rossi LMG, et al. Serum mannose-binding lectin concentrations are linked with respiratory syncytial virus (RSV) disease. J Clin Immunol. 2008;28:166-173.

23. Roy S, Knox K, Segal SH; the Oxford Pneumococcal Surveillance Group. MBL genotype and risk of invasive pneumococcal disease: a case-control study. Lancet. 2002;359:1569-1573.

24. Ip WKE, Chan KH, Law HKW, et al. Mannose-binding lectin in severe acute respiratory syndrome coronavirus infection. J Infect Dis. 2005;191:1697-1704.

25. Eisen DP, Dean MM, Boermeester MA, et al. Low serum mannosebinding lectin concentration increases the risk of death due to pneumococcal infection. Clin Infect Dis. 2008;47:510-520.

26. Garcia-Laorden MI, Sole-Violan J, Rodriguez de Castro F, et al. Mannose-binding lectin and mannose-binding lectin-associated serine protease 2 in susceptibility, severity, and outcome of pneumonia in adults. J Allergy Clin Immunol. 2008;122:368-374.

27. Hodge S, Hodge G, Jersmann H, et al. Azithromycin improves macrophage phagocytic function and expression of mannose receptor in chronic obstructive pulmonary disease. Am J Respir Crit Care Med. 2008;178:139-148.

28. Hodge S, Matthews G, Dean MM, et al. Therapeutic role for mannosebinding lectin in cigarette smoke-induced lung inflammation? Evidence from a murine model. Am J Respir Cell Mol Biol. 2010;42: 235-242.

29. Dahl M, Tybjaerg-Hansen A, Schnohr P, Nordestgaard BG. A polulation-based study of morbidity and mortality in mannose-binding lectin deficiency. J Exp Med. 2004;199:1391-1399.

30. Yang IA, Sleeney SL, Wolter JM, et al. Mannose-binding lectin gene polymorphism predicts hospital admissions for COPD infections. Genes Immun. 2003;4:269-274.

31. Eagan TML, Aukrust P, Bakke PS, et al. Systemic mannose-binding lectin is not associated with chronic obstructive pulmonary disease. Respir Med. 2010;104:283-290. 
32. Lin C-L, Siu LK, Lin J-C, et al. Mannose-binding lectin gene polymorphism contributes to recurrence of infective exacerbation in COPD patients. Chest. 2011;139:43-51.

33. Albert RK, Connett J, Bailey WC, et al; COPD Clinical Research Network. Azithromycin for prevention of exacerbations of COPD. N Engl J Med. 2011;365:689-698.

34. Niewoehner DE, Rice K, Cote C, et al. Prevention of exacerbations of chronic obstructive pulmonary disease with tiotropium, a once-daily inhaled anticholinergic bronchodilator: a randomized trial. Ann Intern Med. 2005;143:317-326.

35. Minchinton RM, Dean MM, Clark TR, Heatley S, Mullighan CG. Analysis of the relationship between mannose-binding lectin (MBL) genotyhpe, MBL concentrations and function in an Australian blood donor population. Scand J Immunol. 2002;56:630-641.

36. Saevarsdottir S, Kristjansdottir H, Grondal G, VikingsdottirT, Steinsson K. Mannan-binding lectin and complement $\mathrm{C} 4 \mathrm{~A}$ in Icelandic multicase families with systemic lupus erythematosus. Ann Rheum Dis. 2006;65:1462-1467.

37. Christiansen OB, Kilpatrick DC, Souter V, Varming K, Thiel S, Jensenius JC. Mannan-binding lectin deficiency is associated with unexplained recurrent miscarriage. Scand J Immunol. 1999;49:193-199.

38. Steffensen R, Thiel S, Varming K, Jersild C, Jensenius JC. Detection of structural gene mutations and promoter polymorphisms in the mannan-binding lectin (MBL) gene by polymerase chain reaction with sequence-specific primers. J Immunol Methods. 2000;241: 33-42.

39. Peterslund NA, Koch C, Jensenius JC, Thiel S. Association between deficiency of mannose-binding lectin and severe infections after chemotherapy. Lancet. 2001;358:637-638.

40. Kruse C, Rosgaard A, Steffesnsen R, Varming K, Jensenius JC, Christiansen OB. Low serum concentration of mannan-binding lectin is a determinant for pregnancy outcome in women with recurrent spontaneous abortion. Am J Obstet Gynecol. 2002;187:1313-1320.
41. Ezekowitz RA, Day LE, Herman GA. A human mannose-binding protein is an acute-phase reactant that shares sequence homology with other vertebrate lectins. J Exp Med. 1988;167:1034-1046.

42. Thiel S, Holmskov U, Hviid L, Laursen SB, Jensenius JC. The concentration of the C-type lectin, mannan-binding protein, in human increases during an acute phase response. Clin Exp Immunol. 1992;99:311-315

43. van Till JWO, Boermeester MA, Modderman PW, et al. Variable mannose-binding lectin expression during postoperative acute-phase response. Surg Infect (Larchmt). 2006;7:443-452.

44. Ip W, To YF, Cheng SK, Lau YL. Serum mannose-binding lectin concentrations and mbl2 gene polymorphisms in different age and gender groups of southern Chinese adults. Scand J Immunol. 2004;59: 310-314.

45. Dommett RM, Klein N, Turner MW. Mannose-binding lectin in innate immunity: past, present and future. Tissue Antigens. 2006;68: 193-209.

46. Dean MM, Minchinton RM, Heatley S, Eisen DP. Mannose binding lectin acute phase activity in patients with severe infection. J Clin Immunol. 2005;25:346-352.

47. Bouwman LH, Roep BO, Roos A. Mannose-binding lectin: clinical implications for infection, transplantation, and autoimmunity. Hum Immunol. 2006;67:247-256.

48. Eisen DP. Mannose-binding lectin deficiency and respiratory tract infection. J Innate Immun. 2010;2:114-122.

49. Kuipers S, Aerts PC, van Dijk H. Differential microorganism-induced mannose-binding lectin activation. FEMS Immunol Med Microbiol. 2003;36:33-39.
International Journal of COPD

\section{Publish your work in this journal}

The International Journal of COPD is an international, peer-reviewed journal of therapeutics and pharmacology focusing on concise rapid reporting of clinical studies and reviews in COPD. Special focus is given to the pathophysiological processes underlying the disease, intervention programs, patient focused education, and self management protocols

\section{Dovepress}

This journal is indexed on PubMed Central, MedLine and CAS. The manuscript management system is completely online and includes a very quick and fair peer-review system, which is all easy to use. Visit http://www.dovepress.com/testimonials.php to read real quotes from published authors. 